\title{
Antecedents of Student Loyalty Within Universities in North Sumatra Province, Indonesia
}

\author{
Hardi MULYONO ${ }^{1}$
}

Received: September 01, 2020 Revised: October 26, 2020 Accepted: November 05, 2020

\begin{abstract}
The purpose of this study was to analyze the antecedents of student loyalty which included Servicescape University, relationship quality, university image, and student satisfaction. The research was conducted in three universities with Islamic atmosphere under Al Washliyah Foundation in Medan, North Sumatra Province, Indonesia. Data analysis in this study includes descriptive analysis and Structural Equation Modeling (SEM). The results showed that: (1) Servicescape university influences university image, student satisfaction, but does not influence student loyalty; (2) Servicescape university through university image influences student loyalty, (3) Servicescape university through student satisfaction influences student loyalty, (4) Relationship quality influences university image, satisfaction Students, but does not influence student loyalty, (5) Relationship quality through university image influences student loyalty, (6) Relationship quality through student satisfaction influences student loyalty, (7) University image influences student loyalty, and (8). Student satisfaction influences student royalty. The findings of this study suggest that the antecedent of student loyalty in universities with Islamic atmosphere which was examined in this research includes four factors: Servicescape university, quality relationship, university image, and students' satisfaction.
\end{abstract}

Keywords: Student Loyalty, Servicescape University, Relationship Quality, University Image, Student Satisfaction

JEL Classification Code: A23, I23, J28

\section{Introduction}

The development of higher education institutions in Indonesia has rapidly increased especially for private higher education. In 2018, there were 122 public higher education institutions and 3,128 private, and under the Religious Ministry there were 97 public religious higher education institutions and 1,058 private. While under government official, there were 181 institutions. The rapidly increasing number of the higher education institutions cause increased competition among private higher education institutions. This condition implies to managers of the higher education institutions to reformulate

${ }^{1}$ First Author and Corresponding Author. Rector, Lecture, Department of Management, Faculty of Business and Economic, Universitas Muslim Nusantara AI Washliyah, Medan, Indonesia [Postal Address: Jl. Garu II A, Harjosari I, Kec. Medan Amplas, Kota Medan, Sumatera Utara, 20147, Indonesia]

Email: hardimulyono@umnaw.ac.id ; lubisriadilakhir@gmail.com

(c) Copyright: The Author(s)

This is an Open Access article distributed under the terms of the Creative Commons Attribution Non-Commercial License (https://creativecommons.org/licenses/by-nc/4.0/) which permits unrestricted non-commercial use, distribution, and reproduction in any medium, provided the original work is properly cited. their best strategy. One of these is to increase and maintain the loyalty of the students. Research on student loyalty has been implemented in the area of marketing. Student loyalty is a component of competitive advantage. Other researchers stated that student loyalty is an important factor for business success including university (Indriyani et al., 2019, Sari et al., 2019 and Lee and Seong, 2020).

Many factors that influence student loyalty have been examined such as student satisfaction and university reputation/image (Helgesen and Nesset, 2007; Abdullah and Husain, 2000 and Kheiry et ak, 2012), trust and students' perceived value, university image and satisfaction; Satisfaction (Gulid, 2011). The influence of servicescape university on student loyalty is not intensively discussed in literature while many universities decide their strength on specific atmosphere of their campus such as of ethnic and religious nuance). Similarly, partnership quality, as a part of marketing relationships which plays important role in marketing, is not intensively discussed on student loyalty. The foundation of Al Washliyah which has three universities, decided its campus's strength on Islamic Atmosphere and Islamic relationship culture. Even though, these three universities followed the foundation's value, all of them 
have not developed equally. It encourages to examine the determinants of student loyalty of universities with specific atmospheres. In this case we are discussing the Islamic atmosphere. Service quality is a statement about attitudes, the relationship resulting from a comparison between expectations and performance. Another definition of service quality is a measure of the extent to which a service provided can meet customer expectations. There are two main factors affecting service quality, namely expected service and perceived service and the quality of service received or perceived. If the service received or felt is as expected, then the service quality is perceived as good and satisfying.

\section{Literature Review}

\subsection{Student Loyalty}

Many factors influence student loyalty. Helgesen and Nesset (2007) mentioned that university image and satisfaction significantly influenced student loyalty and concluded that student loyalty was influenced by corporate image and students' satisfaction through service quality. Kheiry, et.al. (2012) stated that university image and students' satisfaction affected student loyalty. Yenni (2017) examined the effect of service quality, education facilities, and teaching methods in conjunction with student satisfaction and loyalty of students. The study concluded that the loyalty of the students is affected by the quality of the service through student satisfaction. Loyalty is also affected by the educational facilities through student satisfaction. And loyalty is also influenced by learning through student satisfaction. The student satisfaction was the major driver of student loyalty (Kunanusorn and Puttawong, 2015 and Marini et al., 2019). Weerasinghe and Dedunu (2017) concluded that the quality of academic staff has both direct and indirect impact on students' satisfaction through university image. However, only direct impact of nonacademic staff on students' satisfaction was significant in the Sri Lankan context. University image works as a mediating variable and enhances the impact of quality of academic staff on students' satisfaction. The brand image and satisfaction of universities influence university students' word-of-mouth behavior, including the sharing of satisfying experiences and recommendations to others (Chen, 2016). Based on this description, then the hypothesis can be stated as follows:

\footnotetext{
$\boldsymbol{H}_{\boldsymbol{l}}:$ Students' satisfaction significantly affect student royalty. loyalty

$\boldsymbol{H}_{2}:$ Servicescape University significantly affect student

$\boldsymbol{H}_{3}:$ Relationship quality through student satisfaction has effect on student loyalty

$\boldsymbol{H}_{4}$ : Servicescape university through university image has effect on student loyalty
}

$\boldsymbol{H}_{5}:$ Servicescape university through student satisfaction has effect on student loyalty

$\boldsymbol{H}_{6}:$ Relationship quality through university image has effect on student loyalty

\subsection{Students' Satisfaction}

The definition of satisfaction can be stated based the context of the research. For the education sector, students' satisfaction can be defined as a short term attitude, resulting from an evaluation of a students' educational experiences (Elliott and Healy, 2001). It means that students' satisfaction is a function of relative level of experiences and perceived performance during the study period (Carey, et. al., 2002, Ramadania et al., 2018 and Rahman et al., 2020). Williams et.al. (2015) concluded that relationship quality had significant effect on customer's satisfaction. This conclusion was supported by Nauroozi and Moghadam (2015). Based on the above statements, the following hypothesis can be stated:

$\boldsymbol{H}_{7}:$ Quality relationship significantly affect students' satisfaction

\subsection{University Image}

Abdullah, et.al. (2000) mentioned that image has a positive effect on customer loyalty. Similarly, Adeniji, et.al. (2015) concluded that corporate image significantly influenced customer loyalty. Yang, et.al. (2008) mentioned that relationship quality will be depended by academic quality and student activity on campus. The good relationship between students and campus had a high possibility to improve reputation and university image in education marketing. Based on the above statement, the following hypothesis can be stated.

$$
\begin{aligned}
& \boldsymbol{H}_{\boldsymbol{g}}: \text { University image has significant effect on student } \\
& \text { loyalty } \\
& \boldsymbol{H}_{g} \text { : Quality relationship has significant effect on } \\
& \text { university image }
\end{aligned}
$$

\subsection{Servicescape University}

Servicescape had an effect on the quality, satisfaction and the loyalty (Hussainy, et.al. 2017 and Tran, 2020). Theron ((2017) concluded that the physical element dimensions 'communicators' and 'virtual servicescape' most significantly influenced overall student commitment. Contrary to popular belief, the study revealed that social servicescape did not have a significant impact on student commitment. Kloosterman (2017) concluded that servicescape influenced brand image. While Abdel-Aal and Abbas (2016) stated that servicescape which consists of social and physic are the main driver of image. Based on these explanations, then it can be defined the following hypothesis: 


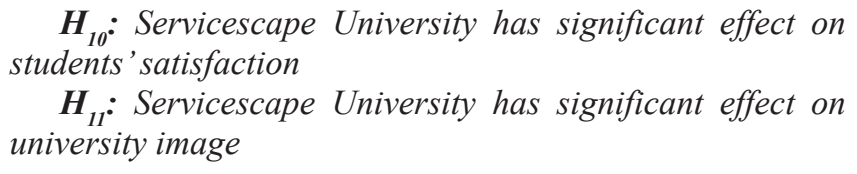

\subsection{Relationship Quality}

Relationship quality has been conceptualized as a construct consisting of several components. These components include satisfaction, trust, commitment, and overall quality among others (Deng, 2009). It was also concluded that relationship quality which consists of two aspects: satisfaction and trust, has a positive effect on student loyalty. Bergamo, et.al., (2007) stated that the relationship with students as a customer is prone to being loyal to their higher education institutions. Relationship quality positively and significantly influences customer loyalty (Lian, 2017; Abdul-Rahman and Kamarulzaman, 2012; Giovanis,; 2015 and Situmorang et al., 2017). Azar and Mahrani (2017) concluded that relationship marketing has six key components of trust, bonding, relationship, shared values, empathy and reciprocity that impact the brand equity. Based on the above mentioned statements, following hypothesis can be arrived at:

\section{$\boldsymbol{H}_{12}:$ Relationship quality has significant effect on student loyalty}

\section{Methods}

This study was conducted in three Islamic universities under Al Washliyah in North Sumatra Province, namely: University of Muslim Nusantara Al Washliyah, Islamic University of Al Washliyah in Medan, and Islamic University of Al Washliyah in Labuhan Batu. The three universities have different numbers of students body. The population of this research are students in the last semester (semester VII). These students were selected because they already have experiences of services provided by the universities. The population of this research was 2.992 students from three universities. Sample of the research was selected using Multi Stage Random Sampling Technique where the first stage was to select study programs using proportional random cluster sampling, and the second stage to select students using incidental sampling. Slovin Formula was used and the sample size of this research was 352 students with the following composition: 200 students from University of Muslim Nusantara Al Washliyah, 77 students from Islamic University of Al Washliyah in Medan, and 75 students from Islamic University of Al Washliyah in LabuhanBatu.

There were five variables of this research which are reflected by dimension. Each dimension was reflected by three indicators as described below:
1. Variable student loyalty reflected by four dimensions: repeat, reward, retention, and referral.

2. Variable student satisfaction reflected by six dimensions: teaching and learning process, curriculum, leadership, lecturer, facility, and administration service;

3. Variable university image, reflected by four dimensions: lecturer image, institution image, study program image, and graduate image;

4. Variable servicescape university, reflected by four dimensions: physical, social, social symbol, and nature of environment.

5. Variable relationship quality, reflected by three dimensions: trust, commitment, and consistency.

These universities decide to create Islamic nuance as their strengths, this is reflected in the following aspects:

1. Islamic component in syllabi

2. Understanding of lecturer in Islamic norms and knowledge

3. Students and lecturer's activities on Islamic development

4. Campus environment with Islamic nuance

5. Worship time has to follow during teaching time.

6. Student's ability to read Al Quran as a requirement to finish the study

7. The development of Islamic Characteristics for student is the main basis

8. The relationship on campus follows Islamic norms.

9. Dressing in campus has to follow Islamic norms

10. Availability of a mosque for worship.

Data were collected by using a questionnaire, interview with the key persons, and documentation in each university. Data analysis of this research consisted of many stages as described as follows:

1. The first stage of this research was to test the validity and reliability of the instrument. This was conducted to thirty students and the result showed that the instrument is valid and reliable.

2. The second stage was to analyze the characteristic of the respondents based on age, working status, living status, type of higher education, and Al Washliyah family status,

3. The third stage analyzed the answers of respondents on each variable, dimensions, and indicators.

4. The fourth stage analyzed the influences among variables for the direct effect, the indirect effect, and the total effect.

5. The fifth stage analyzed the result of the research.

The model of this research was Structural Equation Modeling (SEM) that was solved by using SmartPLS software with the Second Order Model. 


\section{Results and Discussion}

\subsection{Descriptive Statistics}

This statistics gives detailed description of respondents used for the study and answers of respondents on each variable.

\subsubsection{Characteristic of the Respondents}

Characteristic of the respondents can be described as follows:

a. Based on Sex there were 92 males $(26.23 \%)$, and 260 females $(73.77 \%)$. This indicates the female has a high chance to attend higher education, not as stated long ago that female just stay at home.

b. Based on age, the average of student's age is 22.02 years. This value is slightly above normal age because in the private universities many students are working during their study. This is different from public universities where most students only studied and did not work.

c. Based on working status. There were 128 working students (36.34\%) and 224 students who were not working (63.66\%). To accommodate the working students, the private universities provide after- working-hour classes (evening class).

d. Based on living status. There were 236 students $(67.21 \%)$ living with family and parents and 116 students (32.79\%) living with no family. This indicates many of the students are from out of town where the university is located.

e. Based on the type of high school graduation. There were 154 students (43.72\%) graduated from general high school, 117 students $(33.33 \%)$ graduated from vocational high school, and 81 students (22.95\%) graduated from religious high school. This is interesting to explain from this value since these universities are Islamic universities and it was expected that the number of students who graduated from religious high schools will be higher than the students who graduated from public high schools and vocational high schools. This can also explain that, in Indonesia, the number of general high schools are many more than the vocational high schools or the religious high schools.

f. Based on Al Washliyah family status. There were 166 students $(46.72 \%)$ from Al Washliyah family, and 186 students $(53.28 \%)$ from $\mathrm{Al}$ Washliyah family. This indicates that Al Washliyah family is loyal to Al Washliyah organization and institution.

\subsubsection{Answers of Respondents on Variables of the Research}

Answers of respondents can be categorized into five categories based on the score average with the following interval value: very low (1-1.8), low (1.81-2.6), medium (2.61-3.4), high (3.41-4.2), and very high (4.21-5.0).
The answers of respondents on each variable of the research can be described as below.

\section{a. Student loyalty variable}

The average score of the answer of respondents for four dimensions are as follows: Repeat (3.4833, high), Reward (3.9467, high), Retention (4.1567, high), Referral (3.76, high). It shows that students are loyal as far as retention is concerned, i.e. students will stay until they finish their study.

\section{b. Student satisfaction variable}

The average score of the answer of respondent for six dimensions are as follows: Teaching and learning process (3.5733, high), Curriculum (3.8667, high), leadership (3.9233, high), lecturer (3.7933, high), Facility (3.34, medium), and administrative service (3.3033, medium). It shows that administrative service is still bad. If it is observed in more detail, the worst of this service is the speed to administration tasks process is still low. The second worst is the facility. From curriculum can be mentioned that the highest mean is on the curriculum creating Islamic characteristics and followed by syllabi contains Islamic norms.

\section{c. University image variable}

The average score of the answers of respondents on the four dimensions of university image is as follows: Lecturer image (3.8033, high), Institution image (3.9267, high), study program image (3.9267, high), and graduate image (3.7933, high). It shows that institution image and study program image have the highest average score. It means that institution image and study program image already have high value to reflect the university image. If it is analyzed in more detail, image as an Islamic campus has the highest score (4.1.), and followed by Islamic characteristics (3.92). The graduate image has still a low average score to reflect university image. This indicates that the graduates of these universities are still not very good.

\section{d. Servicescape university variable}

The answers of the respondents on servicescape can be analyzed from each dimension as follows: Physics (3.8867, high), Social (3.81, high), Social symbol (4.15, high), and natural environment (3.98, high). It shows that social symbol has the highest score that is reflected by the Islamic symbol as the graduate's requirement with average score 4.33 , followed by Islamic symbol for dressing in campus (4.14), and Islamic symbol for teaching (3.98).

\section{e. Relationship quality variable}

The answers of the respondents on relationship quality can be described from each dimension as follow: Trust (3.7633, high), Commitment (3.8767, high), and Consistent (3.4567, high). It shows that commitment has the highest score average which is reflected by Commitment score to increase loyalty to Al Washliyah (3.93, High), Commitment to increasing Islamic faith 
((3.86, High), and Improve Islamic character (3.84, high). It reflects that Islamic nuance has the main factors in relationship on campus.

f. Among all variables, it shows that the average score of each is as follows: Student Loyalty (3.63, High), Student satisfaction (3.59, High), University image (3.86, High), Servicescape University (3.86, High), and Relationship quality (3.95, High). It shows that the students stated that relationship quality has the highest value among all variables, followed by servicescape university and university image. Students' satisfaction is still not so good, the same for student loyalty. It means that student loyalty is still needed to be improved.

\subsubsection{Validating Measurement Model and Validating Structural Model}

In this research, in order to test the construct validity, composite reliability coefficient was chosen instead of Cronbach's alpha coefficient. This is chosen, according to Götz, et.al. (2010) and Lutz and Thompson (2003), composite reliability provides a much less biased estimate of reliability than Cronbach's alpha coefficient. To test the reliability, convergent validity and discriminant validity of all the items in the measurement scale, the confirmatory factor analysis (CFA) was conducted, as shown in Table 1.

Table 1: Reliability and Validity of Constructs

\begin{tabular}{|c|c|c|c|c|c|}
\hline Constructs & Dimension & $\begin{array}{c}\text { Cronbach's } \\
\text { Alpha }\end{array}$ & $\begin{array}{l}\text { Composite } \\
\text { Reliability }\end{array}$ & $\begin{array}{l}\text { Average } \\
\text { Variance } \\
\text { Extracted }\end{array}$ & $\mathbf{R}^{2}$ \\
\hline \multirow[t]{5}{*}{ STUDENT LOYALTY } & & 0.866 & 0.891 & 0.739 & 0.408 \\
\hline & Repeat & 0.734 & 0.805 & 0.580 & 0.586 \\
\hline & Reward & 0.712 & 0.841 & 0.641 & 0.677 \\
\hline & Retention & 0.741 & 0.807 & 0.583 & 0.675 \\
\hline & Referral & 0.857 & 0.913 & 0.778 & 0.600 \\
\hline \multirow[t]{7}{*}{ STUDENT SATISFACTION } & & 0.942 & 0.949 & 0.508 & 0.615 \\
\hline & Teaching and Learning Process & 0.900 & 0.938 & 0.834 & 0.647 \\
\hline & Curriculum & 0.762 & 0.865 & 0.684 & 0.638 \\
\hline & Leadership & 0.840 & 0.903 & 0.757 & 0.671 \\
\hline & Lecturer & 0.883 & 0.928 & 0.812 & 0.637 \\
\hline & Facility & 0.833 & 0.900 & 0.750 & 0.756 \\
\hline & Administration Services & 0.805 & 0.885 & 0.720 & 0.674 \\
\hline \multirow[t]{5}{*}{ UNIVERSITY IMAGE } & & 0.914 & 0.927 & 0.517 & 0.676 \\
\hline & Lecturer Image & 0.823 & 0.894 & 0.739 & 0.735 \\
\hline & Institution image & 0.763 & 0.863 & 0.677 & 0.742 \\
\hline & Study Program Image & 0.704 & 0.834 & 0.628 & 0.727 \\
\hline & Graduate Image & 0.870 & 0.920 & 0.794 & 0.721 \\
\hline \multirow{5}{*}{$\begin{array}{l}\text { SERVICESCAPE } \\
\text { UNIVERSITY }\end{array}$} & & 0.914 & 0.927 & 0.516 & \\
\hline & Physics & 0.823 & 0.894 & 0.738 & 0.683 \\
\hline & Social & 0.804 & 0.884 & 0.718 & 0.736 \\
\hline & Social Symbol & 0.776 & 0.870 & 0.691 & 0.765 \\
\hline & Natural & 0.786 & 0.875 & 0.701 & 0.718 \\
\hline \multirow[t]{4}{*}{ RELATIONSHIP QUALITY } & & 0.891 & 0.912 & 0.538 & \\
\hline & Trust & 0.877 & 0.924 & 0.803 & 0.776 \\
\hline & Commitment & 0.752 & 0.858 & 0.669 & 0.727 \\
\hline & Consistency & 0.793 & 0.879 & 0.709 & 0.717 \\
\hline
\end{tabular}


Table 1 shows each construct and dimension as well, has composite reliability above 0,7 , thus the reliability of outer model is accepted. Validity test of outer model which is used is convergent validity and discriminant validity. The convergent validity is based on average variance extracted (AVE) of each construct. Hair et. al. (2016) mentioned that AVE $\geq 0.5$ is the acceptance for convergence validity. From Table 1 , it is shown that the AVE value for each construct and its dimension is above 0.5 , thus it can be concluded that convergent validity test is accepted. The discriminant validity test of the model can be evaluated by using two methods: (1) By comparing the correlation of each construct with the squared root of the AVE based on Fornell-Lacker criteria, and (2) By comparing loading factor with cross loading of each indicator (Hair et al., 2016). Based on the Fornell-Larcker Criterion and squared root of AVE value as shown in Table 2, it indicates that the value of squared root of AVE $\geq$ coefficient correlation (Fornell-Larcker), thus it can be concluded that the discriminant validity of the model is accepted.

\subsubsection{Inner Model Analysis}

The relationship among all variables in this research is shown in Figure 1. Structural Equation Modeling (SEM) of these relationship can be stated as follows:

Sub model 1 (Direct Effect):

University image $=\mathrm{f}$ (servicescape university, relationship quality), then it can formulated as:

University image $=\rho_{1}$ servicescape university $+\rho_{2}$ relationship quality $+\varepsilon_{1}$

Sub model 2 (Direct Effect):

Student satisfaction $=\mathrm{f}($ servicescape university, relationship quality), then it can be formulated as:

Student satisfaction $=\rho_{3}$ servicescape university + $\rho_{4}$ relationship quality $+\varepsilon_{2}$

Sub model 3: (Direct Effect)

Student loyalty $=\mathrm{f}$ (servicescape university, relationship quality, university image, and student satisfaction), then it can formulated as:

Student loyalty $=\rho_{5}$ servicescape university $+\rho_{6}$ relationship quality $+\rho_{7}$ university image $+\rho_{8}$ student satisfaction $+\varepsilon_{3}$

Tabel 2: Coefficient (FornellLarcker) and Squared Root of AVE

\begin{tabular}{|c|c|c|c|c|c|c|}
\hline Construct & $\begin{array}{l}\text { Student } \\
\text { Loyalty }\end{array}$ & $\begin{array}{c}\text { Student } \\
\text { Satisfaction }\end{array}$ & $\begin{array}{l}\text { University } \\
\text { Image }\end{array}$ & $\begin{array}{c}\text { Servicescape } \\
\text { University }\end{array}$ & $\begin{array}{c}\text { Relationship } \\
\text { Quality }\end{array}$ & $\sqrt{\text { AVE }}$ \\
\hline Student Loyalty & 0.638 & & & & & 0.860 \\
\hline Student Satisfaction & 0.579 & 0.712 & & & & 0.712 \\
\hline University Image & 0.621 & 0.787 & 0.719 & & & 0.719 \\
\hline Servicescape University & 0.525 & 0.734 & 0.806 & 0.718 & & 0.718 \\
\hline Relationship Quality & 0.512 & 0.751 & 0.738 & 0.795 & 0.734 & 0.734 \\
\hline
\end{tabular}

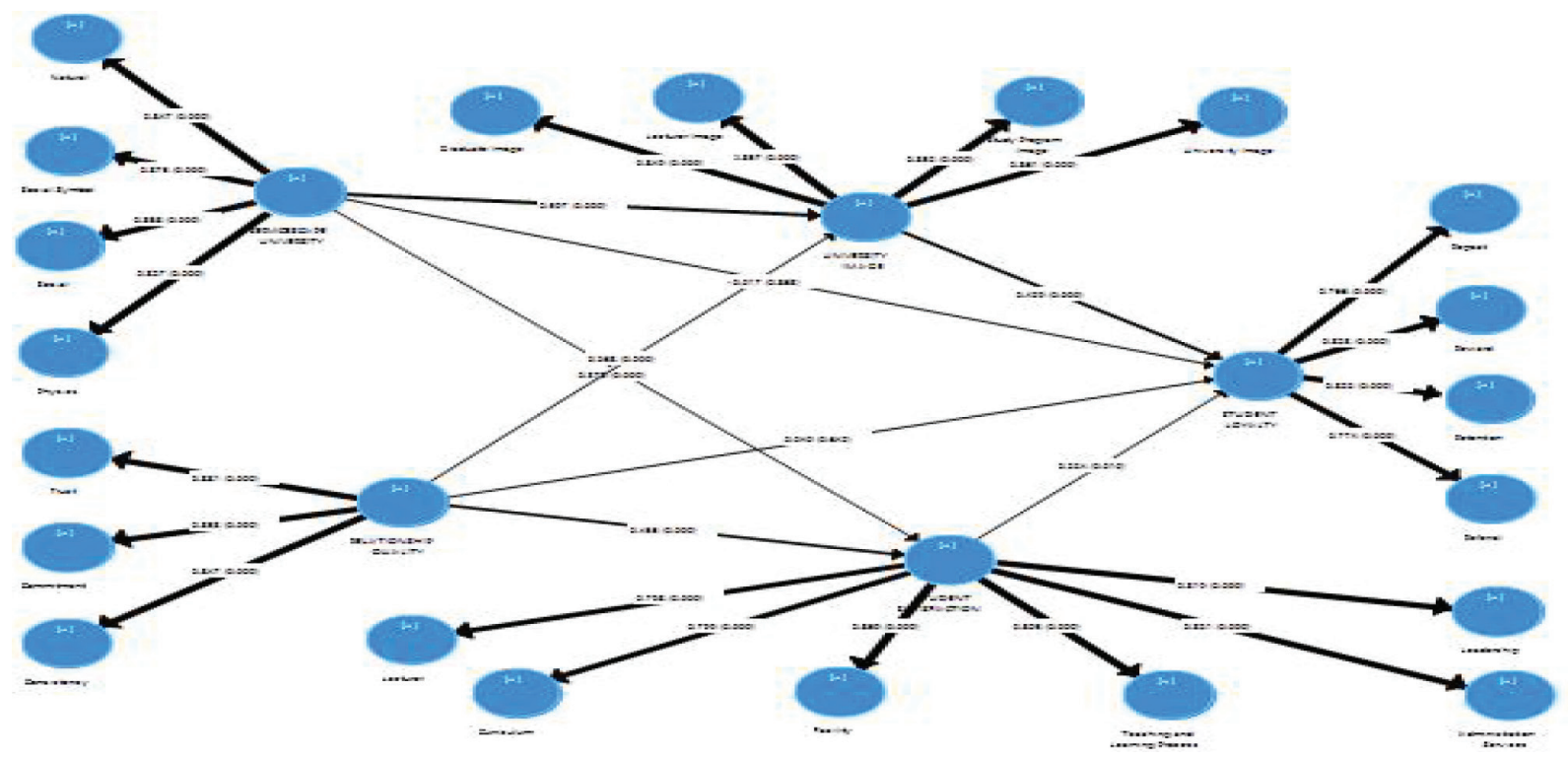

Figure 1: Inner Model 


\section{Sub model 4 (Total Effect)}

Student loyalty $=\mathrm{f}$ (university image)

Where: University image $=\mathrm{f}$ (servicescape university, relationship quality),

Student loyalty $=f($ student satisfaction $)$

Where: Student satisfaction $=\mathrm{f}($ servicescape university, relationship quality)

\subsection{Testing of Hypotheses}

\subsubsection{Direct Effect}

The direct effect of relationship between constructs is summarized in Table 3. Based on the results in Table 3, it shows that the relationship quality has direct effect on student loyalty with a path coefficient 0.040 but not significant since $\mathrm{p}$-value $=0.642>\alpha=0.05$. Relationship quality has significant effect on students' satisfaction with path coefficient 0.455 . Relationship quality also has significant effect on university image with path coefficient 0.263. Similarly, it can be concluded that Servicescape University has effect on student loyalty with path coefficient -0.017 but not significantly. On the contrary, Servicescape University has a significant effect on student loyalty and university image with path coefficient 0.372 , and 0.597 respectively. It can also be concluded that students' satisfaction has significant effect on student loyalty with path coefficient 0.224 . Similarly, university image has significant effect on student loyalty with path coefficient 0.429 . From all variables which has significant effect, can be concluded that the dominant variable that directly affect student loyalty is university image. While the variable that has a dominant effect on student satisfaction is relationship quality, while for university image is servicescape university. These results imply that in order to improve student loyalty the university image is the main factor. While for improving students' satisfaction, the improvement of relationship quality is the main factor. For the improvement of university image, then servicescape is the main factor to be considered has been shown in Figure 1 and Table 3 as follows:

\subsubsection{Indirect Effect}

From Inner Model, Figure 1, it can be obtained that there are two paths from relationship quality toward student loyalty, they are through students' satisfaction and university image. Similarly, for servicescape university, firstly, it can be through student satisfaction, and the secondly, it can be through university image. The value of path coefficient and p-value for each of these combined paths are stated in Table 4. The results shown that relationship quality has a significant effect on student loyalty through students' satisfaction or university with path coefficienta 0.102 and 0.113 respectively. It shows that the effect of relationship quality on student loyalty through university is higher than through students' satisfaction. Similarly, for servicescape university, it shows that relationship quality has significant effect on student loyalty through students' satisfaction or university image with path coefficient 0.083 and 0.256 respectively. It means that enhancing student loyalty can be done firstly by improving servicescape and secondly by enhancing the university image.

\subsubsection{Total Effect}

The total effect, the direct effect + the indirect effect, between constructs (variables) is stated in Table 5. Based on the results, it can concluded that antecedent of student loyalty are all significant. In total, the variable which has the highest effect on student loyalty is serivescape university, followed by university image, relationship quality, and student satisfaction. While, for students' satisfaction, the variable that has the highest effect on students' satisfaction is relationship quality, followed by servicescape university. On the contrary, the variable that has the highest effect on university image is servicescape university, which is followed by the relationship quality.

Table 3: T-Statistics for Path Estimates of Direct Effect

\begin{tabular}{|l|c|c|c|c|}
\hline Hypothesis & $\begin{array}{c}\text { Path } \\
\text { Coefficient }\end{array}$ & t-test & p-value & Result \\
\hline Relationship Quality $\rightarrow$ Student Loyalty & 0.040 & 0.465 & 0.642 & Reject \\
\hline Relationship Quality $\rightarrow$ Student Satisfaction & 0.455 & $8.025^{* *}$ & 0.000 & Accept \\
\hline Relationship Quality $\rightarrow$ University Image & 0.263 & $4.092^{* *}$ & 0.000 & Accept \\
\hline Servicescape University $\rightarrow$ Student Loyalty & -0.017 & 0.173 & 0.863 & Reject \\
\hline Servicescape University $\rightarrow$ Student Satisfaction & 0.372 & $6.470^{* *}$ & 0.000 & Accept \\
\hline Servicescape University $\rightarrow$ University Image & 0.597 & $9.767^{* *}$ & 0.000 & Accept \\
\hline Student Satisfaction $\rightarrow$ Student Loyalty & 0.224 & $2.585^{* *}$ & 0.010 & Accept \\
\hline University Image $\rightarrow$ Student Loyalty & 0.429 & $4.842^{* *}$ & 0.000 & Accept \\
\hline
\end{tabular}

Note: ** significant at $5 \%$ level $(t>1.96)$. 
Table 4: T-Statistics for Path Estimates of Indirect Effect

\begin{tabular}{|l|c|c|c|c|}
\hline Hypothesis & $\begin{array}{c}\text { Path } \\
\text { Coefficient }\end{array}$ & t-test & p-value & Result \\
\hline $\begin{array}{l}\text { Relationship Quality } \rightarrow \text { Student Satisfaction } \rightarrow \\
\text { Student Loyalty }\end{array}$ & 0.102 & $2.376^{* *}$ & 0.018 & Accept \\
\hline $\begin{array}{l}\text { Relationship Quality } \rightarrow \text { University Image } \rightarrow \\
\text { Student Loyalty }\end{array}$ & 0.113 & $3.474^{* *}$ & 0.001 & Accept \\
\hline $\begin{array}{l}\text { Servicescape University } \rightarrow \text { Student Satisfaction } \rightarrow \\
\text { Student Loyalty }\end{array}$ & 0.083 & $2.438^{* *}$ & 0.015 & Accept \\
\hline $\begin{array}{l}\text { Servicescape University } \rightarrow \text { University Image } \rightarrow \\
\text { Student Loyalty }\end{array}$ & 0.256 & $3.983^{* *}$ & 0.000 & Accept \\
\hline
\end{tabular}

Note: ** significant at $5 \%$ level $(t>1.96)$.

Table 5: T-Statistics for Path Estimates of Total Effect

\begin{tabular}{|l|c|c|c|c|}
\hline Hypothesis & $\begin{array}{c}\text { Path } \\
\text { Coefficient }\end{array}$ & t-test & p-value & Result \\
\hline Relationship Quality $\rightarrow$ Student Loyalty & 0.255 & $3.414^{* *}$ & 0.001 & Accept \\
\hline Relationship Quality $\rightarrow$ Student Satisfaction & 0.455 & $8.025^{* *}$ & 0.000 & Accept \\
\hline Relationship Quality $\rightarrow$ University Image & 0.263 & $4.092^{* *}$ & 0.000 & Accept \\
\hline Servicescape University $\rightarrow$ Student Loyalty & 0.323 & $4.123^{* *}$ & 0.000 & Accept \\
\hline Servicescape University $\rightarrow$ Student Satisfaction & 0.372 & $6.470^{* *}$ & 0.000 & Accept \\
\hline Servicescape University $\rightarrow$ University Image & 0.597 & $9.767^{* *}$ & 0.000 & Accept \\
\hline Student Satisfaction $\rightarrow$ Student Loyalty & 0.224 & $2.585^{* *}$ & 0.010 & Accept \\
\hline University Image $\rightarrow$ Student Loyalty & 0.429 & $4.842^{* *}$ & 0.000 & Accept \\
\hline
\end{tabular}

Note: ** significant at $5 \%$ level $(t>1.96)$.

\subsection{Discussion}

Based on the previous discussion, the answers of all hypotheses of this research is summarized in Table 6 . Servicescape university has a significant effect on university image. This conclusion supports Abdel-Aal and Abbas (2016); and Kloosterman (2017). Servicescape university has a significant effect on students' satisfaction. This conclusion is in line with the conclusion by Hussainy, et.al. (2017) and Theron ((2017). Servicescape university has a significant effect on student loyalty but not significantly. This contradicts the conclusion by Hussainy, et.al. (2017) that concluded that servicescape had an effect on quality, satisfaction, and loyalty. However, Servicescape university through student satisfaction has a significant effect on student loyalty. These statements imply that servicescape university has significant effect on loyalty if it is followed by either students' satisfaction or the university image.

The conclusion from Table 6 is that the relationship quality has a significant effect on university image. This conclusion is in line with conclusion stated by Deng
(2009), and Bergamo, et.al. (2007). Similarly, relationship quality has a significant effect on students' satisfaction. This conclusion supports statement of Azar and Mahrani (2017) which stated that relationship marketing has six key components of trust, bonding, relationship, shared values, empathy and reciprocity that their impact on brand equity. Relationship quality has effect on student loyalty but it is not significant. This conclusion contradicts with conclusion stated by Lian (2017); Abdul-Rahman and Kamarulzaman (2012); and Giovanis (2015). However, relationship quality through university image has an effect on student loyalty. Similarly, Relationship quality through student satisfaction has an effect on student loyalty. These statements imply that relationship quality has a significant effect on loyalty if it is followed by either students' satisfaction or university image. University image has a significant effect on student loyalty. This conclusion is in line with conclusion stated by Helgesen and Nesset (2007), and (Chen, 2016). Students' satisfaction has a significant effect on student royalty. This conclusion is in line with conclusion proposed by Helgesen and Nesset (2007) and Kunanusorn and Puttawong, (2015). 
Table 6: Answers of Research Hypotheses

\begin{tabular}{|c|l|c|}
\hline No & \multicolumn{1}{|c|}{ Hypotheses } & Result \\
\hline 1 & $\begin{array}{l}\text { Servicescape university has a significant } \\
\text { effect on university image }\end{array}$ & Accept \\
\hline 2 & $\begin{array}{l}\text { Servicescape university has a significant } \\
\text { effect on students' satisfaction }\end{array}$ & Accept \\
\hline 3 & $\begin{array}{l}\text { Servicescape university has a significant } \\
\text { effect on student loyalty }\end{array}$ & Reject \\
\hline 4 & $\begin{array}{l}\text { Servicescape university through university } \\
\text { image has effect on student loyalty }\end{array}$ & Accept \\
\hline 5 & $\begin{array}{l}\text { Servicescape university through student } \\
\text { satisfaction has effect on student loyalty }\end{array}$ & Accept \\
\hline 6 & $\begin{array}{l}\text { Relationship quality has a significant effect } \\
\text { on university image }\end{array}$ & Accept \\
\hline 7 & $\begin{array}{l}\text { Relationship quality has a significant effect } \\
\text { on students' satisfaction }\end{array}$ & Accept \\
\hline 8 & $\begin{array}{l}\text { Relationship quality has a significant effect } \\
\text { on student loyalty }\end{array}$ & Reject \\
\hline 12 & $\begin{array}{l}\text { Relationship quality through university } \\
\text { image has effect on student loyalty }\end{array}$ & Accept \\
\hline 10 & $\begin{array}{l}\text { Relationship quality through student } \\
\text { satisfaction has effect on student loyalty }\end{array}$ & Accept \\
\hline 11 & $\begin{array}{l}\text { University image has a significant effect on } \\
\text { student loyalty }\end{array}$ & Accept \\
\hline & $\begin{array}{l}\text { Students' satisfaction has a significant } \\
\text { effect on student royalty. }\end{array}$ & Accept \\
\hline
\end{tabular}

Students' satisfaction: on the contrary, quality relationship through students' satisfaction has an effect on student loyalty which is higher than through the university image. Servicescape university has a significant effect on university image and on students' satisfaction. Likewise, quality relationship has significant effect on university image and on students' satisfaction. University image, and students' satisfaction as well, has a significant effect on student loyalty. Servicescape university which is reflected by Islamic nuances, has an effect on student loyalty if it is followed by students' satisfaction or university image. Similarly, quality relationship which is reflected by Islamic norms, has an effect on student loyalty if it is followed by students' satisfaction or university image. In total, student loyalty is dominantly affected by servicescape university, thus it is suggested leaders of universities under Al Washliyah to improve their servicescape university which is reflected by physical aspects, social aspects, social symbols, and Islamic environment. Directly speaking, student loyalty is dominantly affected by university image. To improve university image, the leaders are suggested to improve lecturer image, institution image, study program image, and graduation image. The main focus on building Islamic characteristics for graduates should be defended. This research can be developed by taking other factors to be considered such as culture, service quality, and community support. Another suggestion for the future research is to do a comparison among three universities with Islamic environment within Al Washliyah Foundation.

\section{Conclusion}

The antecedent of student loyalty in university with Islamic atmosphere which was examined in this research includes four factors: Servicescape university, quality relationship, university image, and students' satisfaction. Servicescape university, in direct way, does not significantly affect student loyalty, but it does have an effect in an indirect way. Similarly, quality relationship, in direct ways, does not significantly affect student loyalty, but in an indirect way. Servicescape through university image has an effect on student loyalty higher than through student satisfaction.

\section{References}

Abdel-Al, E., \& Abbas, J. E. (2016). Assessing Social and Physical Servicescape as Drivers of Hotels' Image Formation: Customers Perspective. International Journal of Heritage, Tourism, and Hospitality, 10(1), 27-41.

Abdullah, M., Al-Nasser, A. D., \& Husain, N. (2000). Evaluating functional relationship between image, customer satisfaction and customer loyalty using general maximum entropy. Total Quality Management, 11, 826-82. https://doi. org/10.1080/09544120050008273

Abdul-Rahman, M., \& Kamarulzaman, Y, (2012). The influence of relationship quality and switching costs on customer Loyalty. Social and Behavioral Sciences, 62. 1023-1027. https://doi. org/10.1016/j.sbspro.2012.09.174

Adeniji, A. A., Osibanjo, A. O., \& Oni, O. (2015). Corporate Image: A Strategy for Enhancing Customer Loyalty and Profitability, Journal of South African Business Research, 15(2). 217-234.

Azar, N. K., \& Mehrani, H. (2017). The Effect of Relationship Marketing Orientation on Brand Equity. International Review of Management and Marketing, 7(5), 153-163. https://doi. org/10.1016/j.sbspro.2012.09.174

Bergamo, V. C., Macedo, B., \& Ponchio, M. C. (2012). Student loyalty based on relationship quality: An analysis on higher education institutions, Brizilian Business Review, 9(2), 26-46. http://dx.doi.org/10.15728/bbr.2012.9.2.2

Carey, K., Cambiano, R., \& De Vore, J. (2002). Student to faculty satisfaction at a Midwestern university in the USA. 93-97. DOI: 10.12691/education-5-5-9

Chen, C. T. (2016). The Investigation on Brand Image of University Education and Students' Word-of-Mouth Behavior, Journal of Commercial Design and Management, 6(4), 23-33. https://eric. ed.gov/?id=EJ1113496 
Deng, Z., Lu, Y., \& Zhang, J. (2009). Understanding Customer Satisfaction and Loyalty in China. International Journal of Information Management, 30, 289-300. https://doi. org/10.1016/j.ijinfomgt.2009.10.001

Elliott, K. M., \& Healy, M. A. (2001). Key factors influencing student satisfaction related to recruitment and retention. Journal of Marketing for Higher Education, 10(4), 1-11. https://doi. org/10.1300/J050v10n04_01

Giovanis, A. (2015). Relationship quality and consumer loyalty in high-tech services: International Journal of Strategic Innovative Marketing, 2(2), 1-15.

Götz, O., Liehr, G. K., \& Krafft, M. (2010). Evaluation of Structural Equation Models Using the Partial Least Squares (PLS) Approach. In: Handbook of Partial Least Squares (pp. 691-711). http://doi.org/10.1007/978-3-540-32827-8_30.

Gulid, N. (2011). Student loyalty toward master's degree business administration curriculum at Srinakharinwirot University. American Journal of Business Education, 4(8), 49-56.

Hair Jr, J. F., Hult, G. T. M., Ringle, C., \& Sarstedt, M. (2016). A primer on partial least squares structural equation modeling (PLS-SEM). Thousand Oaks, CA: Sage Publications.

Helgesen, O., \& Nesset, E. (2007). What accounts for students' loyalty? Some field study evidence. International Journal of Educational Management, 21(2), 126-143. https://doi. org/10.1108/09513540710729926

Helgesen, O., \& Nesset, E. (2007). Images, satisfaction and antecedents: Drivers of student loyalty? Corporate Reputation Review, 10(1), 38-59. https://doi.org/10.1057/palgrave. crr. 1550037

Hussainy, S. K., Tariq, U., \& Khan, E. (2017). A Preliminary Investigation of the Effects of Servicescape on Consumers' Loyalty Intentions. KASBIT Business Journals, 10, 101-130.

Indriyani, W., \& Aritra, S. (2019). Customer satisfaction as intervening between use Automatic Teller Machine (ATM), Internet Banking and quality of loyalty. International Journal of Financial Research, 10(6), 54-66. https://doi.org/10.5430/ ijfr.v10n6p54

Kheiry, B., Rad, B. M., \& Asgari, O. (2012). University intellectual image impact on satisfaction and loyalty of students. African Journal of Business Management, 6(37), 10205-10211. https:// doi.org/10.5897/AJBM11.434

Kloosterman, M. E. (2017). The Impact of Servicescape on the Brand Image and Brand Identity of Boutique Hotels, Thesis. Haaga-Helia University of Applied Sciences, Finland. https:// www.theseus.fi/handle/10024/126411.

Kunanusorn, A., \& Puttawong, D. (2015). The Mediating effect of satisfaction on student loyalty to higher education institution. European Scientific Journal, 1, 449-469.

Lee, H. J., \& Seong, M. H. (2020). A Study on the Effects of Business Service Quality on Satisfaction, Commitment, Performance, and Loyalty. Journal of Asian Finance, Economics, and Business, 7(9), 439-453. https://doi.org/10.13106/jafeb.2020. vol7.no9.439
Lian, S. B. (2017). The Role of Relationship Quality on Customer Loyalty: The Effectiveness of Strategic Relationship Marketing. The IIER International Conference (Vol. 29, p. 30th)., Tokyo, Japan.

Lutz, A., \& Thompson, E. (2003). Neurophenomenology integrating subjective experience and brain dynamics in the neuroscience of consciousness. Journal of Consciousness Studies, 10(9-10), $31-52$.

Marini, A., Maksum, A., \& Satibi, O., (2019). Model of student character based on character building in teaching learning process. Universal Journal of Educational Research. 7(10). 2089-2097. DOI: 10.13189/ujer.2019.071006

Nauroozi, S. E., \& Moghadam, K. S. (2015). The Study of Relationship Marketing with Customer Satisfaction and Loyalty. International Journal of Innovation and Research in Educational Sciences, 2(2), 96-101.

Rahman, S. M., Mia, M. S., \& Kiatpathomchai, S. (2020). Assessing Students' Satisfaction in Public Universities: Journal of Asian Finance, Economics and Business, 7(8), 323-332. https://doi. org/10.13106/jafeb.2020.vol7.no8.323

Ramadania, W., \& Indra, W. (2018). Experimental Study of Mobile Number Portability: Could It Be a Potential Breakthrough in Indonesia. Journal of Applied Economic Sciences, 13(5). 1246-1259.

Sari, E., Koul, R., Rochanah, S., Arum, W.S.A., (2019). How could management of school environment improve organizational citizenship behaviors for the environment?. Journal of Social Studies Education Research. 10(2), 46-73. https://www. learntechlib.org/p/216595/

Situmorang, S. H., Rini, E. S., \& Muda, I. (2017). Customer Experience, Net Emotional Value and Net Promoter Score on Muslim Middle Class Women in Medan. International Journal of Economic Research. 14(20). 269-283.

Theron, E., \& Pelser, A. (2017). Using servicescape to manage student commitment towards a higher education institution. South African Journal of Higher Education, 31(5), 225-245. http://dx.doi.org/10.28535/31-5-1506.

Tran, V. D. (2020). Assessing the effects of service quality, experience value, relationship quality on behavioral intentions. Journal of Asian Finance, Economics, and Business, 7(3), 167175. https://doi.org/10.13106/jafeb.2020.vol7.no3.167.

Weerasinghe, I. M. S., \& Dedunu, H. (2017). University Staff, Image and Students' Satisfaction in Sri Lanka. IOSR Journal of Business and Management, 19(5), 34-37.

Williams, P., Ashill, N. J., \& Jackson, E. (2015). Relationship quality and satisfaction: Customer-perceived success factors for on-time projects. International Journal of Project Management, 33(8), 1836-1850. https://doi.org/10.1016/j. ijproman.2015.07.009

Yang, S. U., Alessandri, S. W., \& Kinsey, D. F. (2008). An integrative analysis of reputation and relational quality. Journal of Marketing for Higher Education, 18(2), 145-170. https://doi. org/10.1080/08841240802487353. 